\title{
INTUICJA, EMPATIA, MENTALIZACJA - NIESTANDARYZOWALNE UMIEJĘTNOŚCI PRACOWNIKA SOCJALNEGO
}

\author{
Abstract \\ Intuition, empathy, mentalization - non-standardized skills of a social worker
}

Social workers today have at their disposal modern tools (computer programs, computer equipment, smartphones), they have much faster access to information, document patterns, and good practices.

Social work is changing, the competences of social workers are changing. The social work itself as a practical activity is developed thanks to the development of social work as a scientific field. The educational process, currently at the academic level, places emphasis on building relationships between science and practice. The knowledge, skills and competences of graduates are to be the answer of the didactic process to the needs of the social welfare system. The ubiquitous standards are designed to unify both systems, to objectify their principles. In its essence, social work escapes the standards, empowering clients and social workers themselves, incorporating elements that escape standardization and objectification.

About these three elements is this article - the intuition of a social worker, empathy and mentalization.

Key words: social worker, social work, intuition, empathy, mentalization

\section{Wprowadzenie}

Pracownicy socjalni mają dziś do dyspozycji nowoczesne narzędzia (programy komputerowe, sprzęt komputerowy, smartfony), dysponują zdecydowanie szybszym dostępem do informacji, wzorów dokumentów, dobrych praktyk.

Praca socjalna zmienia się, zmieniają się kompetencje pracowników socjalnych. W procesie kształcenia, prowadzonym obecnie na poziomie akademickim, kładzie się nacisk na budowanie związków między nauką i praktyką. Wiedza, umiejętności i kompetencje absolwentów studiów powinny być odpowiedzią procesu dydaktycznego 
na zapotrzebowanie systemu pomocy społecznej. Wszechobecne standardy mają za zadanie ujednolicić oba systemy, zobiektywizować ich zasady.

W moim przekonaniu przynajmniej część istoty pracy socjalnej wymyka się standaryzacji, ponieważ upodmiotowiając klientów oraz samych pracowników socjalnych, zawiera w sobie komponenty, które określa się jako „miękkie rezultaty”. O takich trzech elementach jest ten artykuł - empatii, intuicji i mentalizacji.

Bez wątpienia można stwierdzić, że pracownik socjalny jest zawodem wymagającym profesjonalizmu. Niesienie fachowej pomocy osobom, grupom, społecznościom lokalnym wymaga nie tylko odpowiednich kompetencji teoretycznych oraz praktycznych (opanowania metodologii pomagania). Konieczne są także odpowiednie cechy - specyficznej „osobowości pomagacza”. Osobowość pracownika socjalnego to suma cech, na którą składają się rezultaty uczenia (cechy nabyte) oraz rozwój cech wrodzonych. Jako zespół stałych właściwości i procesów psychicznych zostaje ona ukształtowana w toku procesów psychicznych, powstaje $\mathrm{w}$ toku procesu nauczania i doświadczenia uzyskiwanego podczas pracy zawodowej. Pewne cechy wyrabia się w procesie kształcenia zawodowego, przyswaja umiejętności (na przykład umiejętność czytania i stosowania przepisów prawa, przygotowywania dokumentów administracyjnych). Inne cechy mamy wrodzone i nie poddają się one „obróbce dydaktycznej” (szacunek do drugiego człowieka, wrażliwość, empatia).

Chociaż pracownik socjalny udziela zawodowo porad i wsparcia, korzystając $\mathrm{z}$ dostępnych zasobów instytucjonalnych, posiłkując się w tym procesie wiedzą i umiejętnościami nabytymi w trakcie kształcenia, to także wykorzystuje swoje wrodzone, indywidualne i specyficzne cechy własne. Można nawet stwierdzić, że na tym polega piękno tego zawodu - na indywidualności, niepowtarzalności stron kontaktu pomocowego oraz kontekstu sytuacyjnego.

Zakres tematyczny i kompetencyjny pracy zawodowej próbuje się ujednolicić opracowywanymi standardami: usług, kompetencji zawodowych, pracy socjalnej itd. W tym znaczeniu standard rozumiany jest jako norma, model, wzorzec, ujednolicenie (Kurcz 2002: 105). Coraz większy nacisk kładzie się na parametryzację pracy socjalnej. Od wielu lat pracuje się nad stworzeniem standardu pracy socjalnej, podkreśla się zasadność takich działań (Marszałkowska 2005) i tworzy oficjalne listy umiejętności zawodowych (Kurcz 2002: 107).

Chciałbym zwrócić uwagę na aspekty pracy socjalnej umykające standaryzacji, realizujące „miękkie efekty”. Autorzy podręczników, twórcy list umiejętności i standardów jakby unikają zwrócenia uwagi na fakt, że pracownicy socjalni też są ludźmi. Nie widzą ich jako osób emocjonalnie reagujących na emocje innych. Pracownicy socjalni mają osobiste emocje, które mogą mieć wpływ na relacje zawodowe, na przykład z klientami. Dlatego ważną umiejętnością oraz cechą osób mających za zadanie zrozumieć emocje klienta jest zrozumienie własnych reakcji emocjonalnych. Konieczne jest przecież zachowanie postawy nieoceniającej wobec klienta. W codziennym wykonywaniu obowiązków zawodowych może być ono konfrontowane z własnymi słabościami, emocjami, lękami, uprzedzeniami pracownika socjalnego. 
Pracownicy socjalni też mają słabsze dni, są zmęczeni i zagubieni w rzeczywistości instytucjonalnej, społecznej, ekonomicznej i prawnej. Taki stan przekłada się na jakość kontaktu z drugim człowiekiem - na przykład klientem będącym również w „gorszej formie".

Pracownik socjalny pracuje sobą - swoimi kompetencjami oczywiście, ale także swoim wizerunkiem, swoim stylem życia. Stosując zasady autoprezentacji w relacjach z klientem, pracownik socjalny musi dobrze odgrywać swoją rolę - to znaczy na samym początku kontaktu zdobyć zaufanie klienta. Wzajemne zrozumienie i zaufanie są podstawą procesu pomagania; wtedy klient będzie skłonny podjąć z nami współpracę i przystać na nasze propozycje rozwiązań sytuacji, w której się znajduje.

Autoprezentacja wydaje się przeciwieństwem autentyczności, jest udawaniem kogoś innego, może nawet być kłamstwem (Szmajke 2001: 146). Autoprezentacja to celowe działanie zmierzające do wywołania pożądanego wizerunku własnej osoby (Szmajke 2001: 147), na przykład w celu zdobycia autorytetu, zaufania. Dobrze jest zatem, jeśli pracownik socjalny zdaje sobie sprawę $\mathrm{z}$ tego, jak reagują na niego ludzie, jak go postrzegają, jak odbierają, jakie budzi w nich emocje.

W trakcie zajęć ze studentami zadaję jako pracę niezbędną do zaliczenia przedmiotu przygotowanie nagrania (filmu) wypowiedzi na dowolny temat. A następnie proponuję dokonanie osobistej oceny własnego wystąpienia. Przez większość studentów to zadanie jest uważane za bardzo trudne i obciążające emocjonalnie, chociaż tak naprawdę nikt obcy tego nagrania nie ogląda. Wystarczy sama czynność nagrywania i analizy własnego zachowania, żeby studenci zrozumieli, jak ważne jest to, w jaki sposób nas widzą klienci. Studenci sami potrafią wskazać w nagraniu elementy oddziałujące na nich pozytywnie lub negatywnie oraz sposób korekty elementów nieodpowiednich.

W pracy socjalnej przydatne są umiejętności „miękkie”, pozwalające na przykład „Czytać ludzi”, by ich zrozumieć. Wraz z rosnącym doświadczeniem pracownicy socjalni potrafią zrozumieć człowieka nie poprzez słowa, ale pomimo słów - w sposób intuicyjny. Niekiedy nawet zwraca się uwagę na tę cechę pracy socjalnej z ludźmi, w której czasem znaczenia nabiera nie tyle dobre przeszkolenie, ile doświadczenie i intuicja (Murgatroyd 2000: 16).

Ponieważ pomoc może być udzielana w rozmaitych miejscach i okolicznościach, pracownik socjalny funkcjonuje w różnych przestrzeniach fizycznych, w odmiennych kontekstach sytuacyjnych, ma przecież do czynienia z ludźmi - niepowtarzalnymi, nieporównywalnymi jednostkami. Zestandaryzowanie tego aspektu pracy socjalnej wydaje się raczej niewykonalne, uderzające w istotę tego zawodu. Zwraca się wszak uwagę na różne cechy i umiejętności, które powinien posiadać pracownik socjalny. Mają one być przydatne i użyteczne w procesie świadczenia pomocy. Część z nich to umiejętności „miękkie” i cechy wrodzone. Carl Rogers zwraca uwagę na trzy podstawowe cechy, których posiadanie stanowi warunek skutecznego pomagania - to empatia, ciepło i autentyczność (Murgatroyd 2000: 28). 


\section{Empatia}

Empatia to wniknięcie w osobisty świat innej osoby po to, by ją zrozumieć. Określa się ją jako zdolność do odpowiedniego, emocjonalnego reagowania na rozpoznawane myśli i odczucia innych ludzi (Stach, Stach-Borejko 2016: 18). Ta cecha wymaga od pracownika socjalnego ,jakby” wniknięcia w świat osoby, której udziela pomocy, zrozumienia, a nie oceniania. Można ją określić jako pewną formę wrażliwości na zmienne doznania konkretnej osoby.

Umiejętność ta jest ważna w pracy socjalnej, ponieważ dla klienta sam akt rozmowy z przedstawicielem instytucji jest zdarzeniem emocjonalnie obciążającym. Czy jesteśmy w stanie zapewnić sami siebie, że nasz przekaz został przyswojony, zrozumiany i zapamiętany? Wydaje nam się, że jeżeli tłumaczymy coś w prosty dla nas sposób, to klient powinien rozumieć to zgodnie z naszą intencją. A przecież bardzo różnimy się między sobą, nie istnieje jeden uniwersalny wzorzec porozumiewania się i uczenia. To pracownik socjalny powinien umieć dopasować się do klienta, dotrzeć do niego, podążać za klientem.

Możemy nie dojść z kimś do porozumienia, ponieważ to, co jednej stronie wydaje się oczywiste i już omówione, przez drugą zupełnie nie zostało zrozumiane i zapamiętane.

Chociaż wiele potrafimy zaplanować, by jako pracownicy socjalni ułatwić klientom spotkania z nami, nie możemy zapominać, że to, jak przebiegnie spotkanie, nadal zależy w dużej mierze tylko od naszych predyspozycji osobowościowych (Kaźmierczyk, Łuczyńska 1998). Żadne metody nie zastąpią umiejętności pracy z drugim człowiekiem. Może się okazać, że nic nie zastąpi naszego szczerego uśmiechu.

Ludzie empatyczni potrafią odnaleźć się w takich sytuacjach. Empatia może być „odzwierciedleniem uczuć” - odczytaniem zawartych w przekazie emocji (Murgatroyd 2000).

Pracownicy socjalni powinni umieć rozpoznać (wyczuć), oddzielając komunikat werbalny od komunikatu niewerbalnego, stan emocjonalny swojego klienta. Po tonie głosu, tempie wypowiedzi, głośności, gestykulacji, mimice towarzyszącej słowom można rozpoznać, czy mamy do czynienia z osobą wesołą, radosną, smutną, zagubioną, wystraszoną, nerwową, nieszczęśliwą lub agresywną.

Psychologowie opracowali testy pozwalające ustalić poziom empatii. Każdy może samodzielnie (dla celów rozrywkowych) taki test wykonać. W Internecie można znaleźć testy badające poziom empatii, np. 15 pytań o empatię (Karpowicz 2015). Zaawansowane naukowo testy są oczywiście o wiele bardziej precyzyjne (na przykład Rembowski 1989). Warto również wspomnieć, iż nie ma jednego rodzaju empatii jako umiejętności. Wyszczególnia się na przykład empatię bólu, empatię stanów emocjonalnych, obrzydzenia, smutku, gniewu, żalu itd. (Stach, Stach-Borejko 2016).

Jako cechę przydatną w wielu zawodach, nie tylko w pracy socjalnej, empatię można ćwiczyć (Murgatroyd 2000: 34). Uczy się jej na kursach dla pracowników socjalnych, lekarzy, pielęgniarek, asystentów sprzedaży (na przykład jako rozwój świadomości i umiejętności potrzebnych do asertywnej i empatycznej komunikacji w kontaktach z klientami). Prowadzone są badania porównawcze, na podstawie których powstaje ranking najbardziej „empatycznych krajów” (Nieckuła 2018). Naukowcy z Uniwersytetu 
Stanowego w Michigan podjęli próbę stworzenia takiego rankingu. Przy użyciu ankiety internetowej przebadali ponad 100 tysięcy osób w wieku 18-90 lat w 63 krajach (Warrier i in. 2018).

Z kolei inny zespół naukowców, tym razem z Cambridge, dowodzi, że empatia może być równie dobrze uwarunkowana genetycznie (Piorun 2018).

Pracownicy socjalni doceniają znaczenie emocji w pracy socjalnej i potrafią empatycznie wkroczyć w świat swojego klienta. Empatycznie nie oznacza współodczuwania, a bardziej zrozumienie, co i dlaczego czują inni. Nie muszą odczuwać tych samych emocji, żeby zrozumieć wzburzenie emocjonalne, złość, strach, niechęć, cierpienie itd.

Więcej o historii badań nad empatią, o pochodzeniu nazwy można dowiedzieć się u Józefa Rembowskiego (1989).

\section{Intuicja}

Wiedza i umiejętności profesjonalne (na przykład wykształcenie psychologiczne) nie są jedynym źródłem kompetencji pozwalających „czytać ludzi”. Skuteczni są także nieprofesjonaliści trudniący się pomaganiem, opiekowaniem. Znają praktyczne sposoby pomagania ludziom, posiadają intuicję (Kennedy, Charles 2004: 19) zwaną rozumowaniem intuicyjnym (Wikipedia 2018), pozwalającą im skutecznie pomagać tym, którzy pomocy potrzebują.

Posiadacze intuicji, dzięki skojarzeniom opartym na doświadczeniu i wiedzy, potrafią dostrzec nawet delikatne niuanse w zachowaniu osoby, są w stanie zdecydować się na określoną ścieżkę pomocy, nie umiejąc w danym momencie wyjaśnić racjonalnie, dlaczego wybierają właśnie tę a nie inną drogę - „mam nosa”, „tak czuję”, „wiem, że tak”, „,bo tak będzie dobrze”. Nie chodzi tu o sytuację, w której „ja, pracownik socjalny wiem lepiej”. Chodzi o sytuację, w której „,ja pracownik socjalny czuję, że tak będzie lepiej". Kiedy dowody naukowe są niejasne, a dotychczasowe rozwiązania nieadekwatne do zaistniałej sytuacji, pozostają alternatywne uzasadnienia (Szarfenberg 2011). „Moje dotychczasowe doświadczenie zawodowe/życiowe podpowiada mi, że to będzie najlepsze rozwiązanie”. Intuicja może być rozumiana jako przeczucie opierające się na doświadczeniu i do niego się odnoszące.

Czy jest wystarczającym uzasadnieniem podjętych decyzji? W literaturze prawniczej znajdujemy przykłady badań nad zjawiskiem intuicji sędziowskiej (Zygmunt 2017). Sędziowie orzekający w dowolnych rodzajach spraw w toku swojej praktyki nabrali doświadczenia, które przełożyło się na zdolność do intuicyjnego myślenia i orzekania. W świetle wyników tych badań dowiadujemy się, że myślenie intuicyjne jest jak najbardziej poważnie traktowaną cechą i domeną doświadczonych prawników. Sędzia po przeanalizowaniu sprawy najpierw wie, jaki wyrok wydać, a potem szuka przesłanek do jego wydania. Podnoszono istnienie intuicji eksperckiej trafniejszej niż intuicja nieekspercka (Zyzik 2014). Posługują się nią przedsiębiorcy, menedżerowie; jest traktowana jako zdolność postrzegana w kategoriach kompetencji (Jędrzejczyk 2015). 
Pracownicy socjalni są ekspertami w świadczeniu pomocy ludziom potrzebującym, posiadają odpowiednie kwalifikacje, umiejętności oraz doświadczenie zawodowe i życiowe, więc w przypadku tego zawodu mówi się niekiedy o intuicyjnym reagowaniu.

Nie rozstrzygam w tym miejscu o skuteczności czy trafności działań opartych na intuicji, zwracam jedynie uwagę na samą możliwość istnienia intuicji pracownika socjalnego.

Relacje osób wykonujących ten zawód zawierają przykłady takiego zachowania: „Okazało się, że przeczucie i intuicja pracownika były trafne. W mieszkaniu ulatniał się śmiertelny czad i do tragedii było bardzo blisko”, ",Poprosiłam koleżankę o asystę, bo intuicja podpowiadała mi, że sprawa nie będzie lekka”, „Intuicja podpowiadała, że czym innym będzie praca socjalna wypełniająca założenia profilaktyczne, inna będzie praca socjalna w zakresie interwencji, a jeszcze inna w reintegracji” (Józefczyk 2018: 85).

\section{Mentalizacja}

Wykorzystywanie empatii i intuicji w pracy socjalnej oznacza, że „pomagacze” powinni umieć dopasować się do klienta. Swoje dotychczasowe doświadczenia zawodowe i życiowe powinni wykorzystywać do zindywidualizowania podejścia do klienta - mają podążyć za klientem w swej propozycji wsparcia (Kantowicz 2001).

Chciałbym również zwrócić uwagę pracowników socjalnych na innego rodzaju mechanizm - mentalizację. Rozwijana od początku lat dziewięćdziesiątych XX wieku teoria mentalizacji Petera Fonagy'ego jest stosunkowo nowym, zorientowanym psychoanalitycznie modelem wyjaśniającym prawidłowy i nieprawidłowy rozwój osobowości (Adamczyk 2013). Nie chodzi mi jednak o jej zastosowanie w procesie leczenia zaburzeń osobowości, czemu początkowo służyła. Traktuję mentalizację jako narzędzie (umiejętność) pomocną w rozumieniu człowieka. To zaawansowana funkcja psychiczna, pozwalająca postrzegać siebie i innych przez pryzmat możliwych uczuć, intencji i myśli. Uczymy się tego już jako dzieci, poprzez doświadczenie bycia rozumianymi.

Umiejętność mentalizowania to stan rozumienia siebie i innych, wyciągania wniosków, nazywania uczuć, odzwierciedlania ich u innych osób. Umiejętność ta, poprzez odbieranie i interpretację emocji, jest bardzo istotna w pracy z ludźmi, w relacjach interpersonalnych. W mojej opinii mentalizacja nabiera znaczenia w sytuacji kontaktu z osobami emocjonalnymi.

Mentalizacja polega na postrzeganiu zachowań oraz ich interpretacji odniesionej do nieobserwowalnych bezpośrednio, intencjonalnych stanów mentalnych, takich jak: potrzeby, pragnienia, uczucia, przekonania oraz cele działania podmiotu. Proces

1 Wąbrzeźno: uratowała rodzinę przed czadem; http://federacja-socjalnych.pl/index.php/471-wabrzezno-uratowala-rodzine-przed-czadem (dostęp: 19.02.2018).

${ }^{2}$ Czy pracownik socjalny się boi?, blog Pani socjalna; http://panisocjalna.blogspot.com/2017/08/czy-pracownik-socjalny-sie-boi.html (dostęp: 19.02.2018). 
mentalizacji ma istotne znaczenie dla funkcjonowania jednostki w codziennym życiu, umożliwia bowiem budowanie społecznych relacji i rozumienie zdarzeń o charakterze społecznym (Kossewska 2014:25). W dzieciństwie kształcimy tę umiejętność poprzez odgrywanie ról w trakcie zabaw. Dzieci bawiące się w złodziei i policjantów wcielają się w odgrywane postaci, także emocjonalnie. Ważne, aby zdawały sobie sprawę, że to tylko zabawa, że w rzeczywistości nie są ani złodziejami, ani policjantami. Po skończonej zabawie wracają do swoich właściwych stanów emocjonalnych i ról społecznych. Oczywiście w trakcie udawanej zabawy odczuwają autentyczne emocje - radość, gniew, smutek, lęk. W procesie uczenia się relacji powinien wystąpić element - koniec zabawy.

W kontekście pracy socjalnej mentalizacja może zostać określona jako narzędzie niezbędne i niezwykle przydatne w pracy, której jednym z ważniejszych aspektów są emocje. Mentalizacja nie polega jedynie na rozumieniu stanu drugiej osoby. Odgrywa istotną rolę również $\mathrm{w}$ regulowaniu własnych stanów emocjonalnych w odniesieniu do emocji innych osób (Górska, Marszał 2014) i nie jest tym samym, czym empatia.

Empatia jest umiejętnością współodczuwania stanów innych ludzi i nie zawsze jest ściśle związana z mentalizacją. Chociaż definicje obu pojęć brzmią dość podobnie, to czym innym jest wspólne odczuwanie emocji, a czym innym -rozumienie stanu drugiej osoby. Badania dowiodły, że nadmierna empatia może nawet upośledzić mentalizację, ponieważ w sytuacjach bardzo emocjonalnych u niektórych osób dochodzi do zaburzenia umiejętności zrozumienia stanu innej osoby (Błońska 2016). Jest to dość istotne, jeżeli rozpatrywać mentalizację w kontekście pracy pracownika socjalnego, ponieważ jest to zawód, w którym bardzo często dochodzi do sytuacji wywołujących silne emocje. „Udana interakcja społeczna bazuje na naszej zdolności współodczuwania i rozumienia myśli czy intencji innych ludzi" (Błońska 2016: 79).

Empatyczny pracownik socjalny, reagujący emocjonalnie na emocje lub zachowanie klienta, może doświadczyć rzeczywiście silnych przeżyć związanych z daną sytuacją. Może teoretycznie utracić zdolność obiektywnego podejścia do klienta.

Co się jednak stanie, jeśli ten silny stan emocjonalny pracownika socjalnego został wywołany nie faktycznym, lecz wyobrażonym stanem emocjonalnym klienta? Zwyczajnie doszłoby do nieporozumienia, błędnego „odczytania” klienta.

Mentalizacja jest to zdolność do rozumienia swoich stanów umysłowych oraz innych ludzi. Zdolność ta prowadzi do zrozumienia swojego zachowania oraz innych. Przede wszystkim w kategoriach myśli, uczuć, życzeń oraz pragnień.

Innymi słowy, nasze rozumienie innych i siebie w zasadniczym stopniu jest uzależnione od tego, czy nasze własne stany umysłu były adekwatnie rozumiane przez osoby dla nas ważne.

Zależy to również od obecnej kompetencji w zakresie podtrzymania mentalizacji, jak poczucie zmęczenia oraz kontekst, w jakim się znajdujemy (Biernacki 2017).

Mentalizacja jest nazywana również refleksyjnością, czyli zdolnością do odróżniania zachowań ludzi od ich uczuć, przekonań, motywacji i oczekiwań. Innymi słowy, jest to aktywność umysłowa polegająca na przypisywaniu innym osobom stanów mentalnych (wyobrażonych stanów emocjonalnych), na które reagujemy rzeczywistą emocją. 
Dzięki takiemu działaniu na nas mentalizacja umożliwia przede wszystkim rozumienie zachowań społecznych. Odpowiedzialna jest za tworzenie i podtrzymywanie więzi międzyludzkich. Każdy z nas inaczej mógłby mentalizować tę samą sytuację, na przykład w zależności od poziomu samooceny, obecnego stanu emocjonalnego, zmęczenia psychicznego, nastawienia osobistego do drugiej osoby oraz własnych doświadczeń $\mathrm{w}$ relacjach $\mathrm{z}$ nią.

Mentalizacja zachodzi w różnych wymiarach, a jednym z nich jest mentalizacja skupiona na naszych i innych wewnętrznych versus zewnętrznych cechach.

Mentalizacja może się koncentrować na rzeczywistości wewnętrznej, a mianowicie na myślach, uczuciach i doświadczeniach naszych i innych ludzi, ale może być skupiona na obserwowalnych cechach zewnętrznych oraz na działaniach i zachowaniu (Adamczyk 2013). Gdy zastanawiamy się nad stanem emocjonalnym drugiej osoby, rodzi się pytanie: Czy zachowując się w konkretny sposób, ranimy uczucia tej osoby? Odpowiedź budowana jest na podstawie wywnioskowanych stanów emocjonalnych oraz procesów psychicznych zachodzących u innych. Na podstawie tonu głosu, mimiki, postawy ciała, grymasów i gestów odczytywany jest stan emocjonalny drugiego człowieka.

Można także analizować stany emocjonalne z perspektywy czasu, mentalizować je w odniesieniu do specyficznych stanów psychicznych doświadczanych aktualnie oraz do stanów psychicznych doświadczanych w przeszłości. Daje to zrozumienie niektórych sytuacji dopiero po upływie pewnego czasu. Można wreszcie mentalizować przyszłe procesy i stany psychiczne (Adamczyk 2013).

Zawód pracownika socjalnego jest pracą niejednorodną, w zależności od miejsca zatrudnienia różni się szczegółowymi zadaniami (Urbanek 2012). W każdym przypadku oscyluje jednak wokół podobnych czynności, do których należą:

1. rozumienie i przekazywanie informacji oraz wiedzy;

2. działanie na rzecz zmiany czyjejś postawy, zachowań, przekonań, a nawet osobowości;

3. praca i koordynacja działań, które wymagają współpracy wielu placówek i instytucji;

4. nadzorowanie pracy oraz działalności innych.

Wszystkie te zadania łączy jedno: wymagają dużych umiejętności interpersonalnych, społecznych, a przede wszystkim komunikacyjnych (Nocuń, Szmagalski 1998: 18), które okazują się niezbędne pracownikowi socjalnemu, by mógł działać efektywnie. Można do nich zaliczyć takie umiejętności, jak łatwość w nawiązywaniu kontaktu, prowadzeniu rozmowy, zrozumieniu rozmówcy i sytuacji, negocjowaniu, mediowaniu, okazywaniu empatii; celowe słuchanie innych; tworzenie i podtrzymywanie stosunków interpersonalnych; angażowanie klientów w system pomocowy (Nocuń, Szmagalski 1998).

\section{Zamiast zakończenia}

Celem powyższego artykułu było zwrócenie uwagi na pewne umiejętności przydatne w zawodzie pracownika socjalnego. Pozwalają one lepiej zrozumieć klienta, odpowiednio reagować na jego potrzeby i zachowanie, choćby poprzez to, że umożliwiają 
zrozumienie własnych reakcji i emocji pracownika socjalnego. Umiejętności te można nawet określić jako zdolności, jako talent do pomagania, czyli zasób o wyjątkowym znaczeniu (Białasiewicz 2015).

\section{Bibliografia}

Adamczyk L. (2013). Mentalizacja, cz. 1: Wprowadzenie do zagadnienia. Wymiary mentalizacji; http://www.psychoterapiaptp.pl/uploads/PT_3_2013/Adamczyk25_Psychoterapia3_2013. pdf (dostęp: 21.02.2018).

Białasiewicz M. (2015). Kreatywność i talent w koncepcji kapitału ludzkiego. „Studia i Prace Wydziału Nauk Ekonomicznych i Zarządzania, 39 (1); http://wneiz.pl/nauka_wneiz/sip/ sip39-2015/SiP-39-t1-9.pdf (dostęp: 27.01.2019).

Biernacki P. (2017). Mentalizacja. Fundacja im. Boguchwała Winida na rzecz Rozwoju Psychoterapii Psychoanalitycznej; http://www.zaburzeniaosobowosci.pl/mentalizacja.html (dostęp: 21.02.2018).

Błońska A. (2016). Nadmierna empatia może upośledzać rozumienie innych; http://kopalniawiedzy.pl/empatia-mentalizacja-sieci-mozg-zdolnosci-zrozumienie-pespektywa-poznawcza-dr-Anne-Bockler,24455 (dostęp: 21.02.2018).

Czy pracownik socjalny się boi?, blog Pani socjalna; http://panisocjalna.blogspot.com/2017/08/ czy-pracownik-socjalny-sie-boi.html (dostęp: 19.02.2018).

Górska D., Marszał M. (2014). Mentalizacja i teoria umysłu w organizacji osobowości borderli$n e$ - różnice pomiędzy afektywnymi i poznawczymi aspektami poznania społecznego w patologii emocjonalnej. „Psychiatria Polska” 48 (3): 503-513; http://www.psychiatriapolska.pl/ uploads/images/PP_3_2014/503Gorska_PsychiatrPol2014v48i3.pdf (dostęp: 22.02.2018).

Jędrzejczyk W. (2015). System zarządzania intuicja menedżerska $w$ przedsiębiorstwie - ocena i weryfikacja. „Przegląd Organizacji”, 1: 35-40.

Józefczyk J. (2018). Perspektywy rozwoju pracy socjalnej w Miejskim Ośrodku Pomocy Społecznej w Gdyni; http://www.rodzinablizejsiebie.pl/IMG/pdf/2-_Jaroslaw_Jozefczyk_-_Perspektywy_rozwoju--.pdf (dostęp: 19.02.2018).

Karpowicz I. (2015). 15 pytań o empatię; http://www.wysokieobcasy.pl/wysokieobcasy/ 1,139990,19386034,15-pytan-o-empatie.html?disableRedirects=true (dostęp: 27.01.2019).

Kaźmierczyk T., Łuczyńska M. (1998). Wprowadzenie do pomocy społecznej. Wydawnictwo Śląsk, Katowice.

Kennedy E., Charles S.C. (2004). Jak pomagać dobrą radą. Poradnik, tłum. J. Kołacz SJ. Wydawnictwo WAM, Kraków.

Kossewska J. (2014). Dziecięca agresja a umiejętność mentalizowania. Uniwersytet Pedagogiczny im. Komisji Edukacji Narodowej, „Kwartalnik Edukacja”, 2 (127): 21-36 (dostęp: 20.02.2018).

Kurcz A. (2002). Standardy umiejętności w pracy socjalnej. Samoocena opanowania umiejętności zawodowych przez pracowników socjalnych, w: J. Brągiel, A. Kurcz (red.), Pracownik socjalny. Wybrane problemy zawodu w okresie transformacji spolecznej. Wydawnictwo Uniwersytetu Opolskiego, Opole: 105-114. 
Laboratorium psychoedukacji; https://www.facebook.com/laboratoriumpsychoedukacji/posts/ 540855652624452 (dostęp: 21.02.2018).

Marszałkowska M. (2005). Standardy pracy socjalnej. Raport końcowy. Analiza zasobów. Projekt realizowany w ramach grantu TF052685 Poakcesyjnego Projektu Pomocy dla Obszarów Wiejskich (PARSP), Warszawa.

Murgatroyd S. (2000). Poradnictwo i pomoc, tłum. E. Turlejska. Zysk i S-ka Wydawnictwo, Poznań. Nieckuła E. (2018). Polska na końcu rankingu empatii. Rozumienie innych jest nam obce?; https:// www.focus.pl/artykul/czy-polakom-brakuje-empatii-wyniki-tych-bada-nie-s-najlepsze (dostęp: 27.01.2019).

Nocuń A.W., Szmagalski J. (1998). Podstawowe umiejętności w pracy socjalnej i ich kształcenie. Wydawnictwo Śląsk, Katowice.

Piorun M. (2018). Empatia zależy od... genów! Naukowcy twierdza, że to cecha dziedziczna; https://zdrowie.radiozet.pl/Psychologia/ABC-psychologii/Empatia-zalezy-od-genow! -Nowe-odkrycie-naukowcow-z-Cambridge (dostęp: 27.01.2019).

Rembowski J. (1989). Empatia. Państwowe Wydawnictwo Naukowe, Warszawa.

Rozumowanie intuicyjne [online]. Wikipedia: wolna encyklopedia, 2018-09-20; https:// pl.wikipedia.org/wiki/Rozumowanie_intuicyjne (dostęp: 19.02.2018).

Stach R., Stach-Borejko A. (2016). Empatia i mózg. Wydawnictwo Uniwersytetu Jagiellońskiego, Kraków.

Szarfenberg R. (2011). Dowody naukowe jako podstawa polityki społecznej, zarzadzania społecznego i pracy socjalnej; http://problemypolitykispolecznej.pl/images/czasopisma/15/15_13-28. pdf (dostęp: 27.01.2019).

Szmajke A. (2001). Autoprezentacja - niewinny spektakl dla innych i siebie, w: M. Kofta, T. Szustrowa (red.), Zludzenia, które pozwalają żyć. Wydawnictwo Naukowe PWN, Warszawa: 146-157.

Urbanek A. (2012). Realizacja zadań pracownika socjalnego w praktyce. Państwowa Szkoła Zawodowa w Legnicy, Legnica.

Warrier V., Toro R., Chakrabarti B., the iPSYCH-Broad autism group, Børglum A.D., Grove J., the 23andMe Research Team, Hinds D.A., Bourgeron T., Baron-Cohen S. (2018). Genome-wide analyses of self-reported empathy: Correlations with autism, schizophrenia, and anorexia nervosa; https://www.nature.com/articles/s41398-017-0082-6.pdf (dostęp: 27.01.2019).

Wąbrzeźno: uratowała rodzinę przed czadem; http://federacja-socjalnych.pl/index.php/471-wabrzezno-uratowala-rodzine-przed-czadem (dostęp: 19.02.2018).

Zygmunt T. (2017). Intuicja sędziowska. Internetowy Przegląd Prawniczy TBSP UJ 2017/2018; https://ruj.uj.edu.pl/xmlui/bitstream/handle/item/45168/zygmunt_intuicja_sedziowska_2017. pdf? sequence=1\&isAllowed=y (dostęp: 24.10.2018).

Zyzik R. (2014). Wokót intuicyjnych decyzji sędziego. „Zeszyty Prawnicze”, 14 (2): 187-200; http://bazhum.muzhp.pl/media//files/Zeszyty_Prawnicze/Zeszyty_Prawnicze-r2014-t14-n2/Zeszyty_Prawnicze-r2014-t14-n2-s187-200/Zeszyty_Prawnicze-r2014-t14-n2-s187-200. pdf (dostęp: 24.10.2018). 